\title{
Faktor-Faktor yang Berhubungan dengan Ukuran Keluarga di Indonesia
}

\author{
The Factors Correlate to Family Size in Indonesia
}

\section{Agung Dwi Laksono' dan Ratna Dwi Wulandari²}

\author{
1agung.dwi.laksono-2016@fkm.unair.ac.id \\ Fakultas Kesehatan Masyarakat Universitas Airlangga \\ Jl. Ir. Soekarno, Surabaya 60115 \\ 2ratna-d-w@fkm.unair.ac.id \\ Fakultas Kesehatan Masyarakat Universitas Airlangga \\ Jl. Ir. Soekarno, Surabaya 60115
}

Naskah diterima: 14 Februari 2021 | Naskah direvisi: 19 Mei 2021 | Naskah diterbitkan: 30 Juni 2021

\begin{abstract}
Some tribes in Indonesia have a big family culture. The study aimed to analyze factors that correlate to family size in Indonesia. The study employed secondary data from the 2017 Indonesia's Demographic and Health Survey. The samples used were 34,353 childbearing age couples. The variables analyzed included type of residence, wealth, marital, cohabitation duration, complete child gender, contraceptive, age of husband-wife, education of husband-wife, and occupation of husband-wife. Final test by binary logistic regression. The results show that couples in urban areas are less likely to have a family size $\leq 4$ than couples who live in rural areas. The better the wealth status, the higher the possibility to have a family size $\leq 4$. The longer the cohabitation period, the lower the possibility of having a family size $\leq 4$. Couples who already have complete child gender were 0.148 times more likely to have a family size $<4$ than couples with incomplete child gender. The contraceptives use has a probability of 0.727 times more than those not using it to have a family size $\leq 4$. The husband with primary education was 1.242 times more likely than the husband with no education to have a family size $\leq 4$. The study found that a wife's age correlated to family size. Couples with employed wives were 1.273 times more likely than those not employed to have a family size $\leq 4$. The study concluded that eight variables correlated to family size among childbearing age couples in Indonesia: residence, wealth, cohabitation duration, complete child gender, contraceptive use, husband's education, wife's age, and wife's employment.
\end{abstract}

Keywords: childbearing; family planning; family size; population data

Abstrak: Beberapa suku di Indonesia memiliki budaya keluarga besar yang sangat kuat. Penelitian ini bertujuan untuk menganalisis faktor-faktor yang berkorelasi dengan ukuran keluarga di Indonesia. Studi memanfaatkan data sekunder dari Survei Demografi dan Kesehatan Indonesia tahun 2017. Sampel yang digunakan adalah 34.353 pasangan usia subur. Variabel yang dianalisis meliputi jenis tempat tinggal, kekayaan, perkawinan, lama kohabitasi, kelengkapan jenis kelamin anak, kontrasepsi, umur suami-istri, pendidikan suami-istri, dan pekerjaan suami-istri. Pengujian akhir 
dengan regresi logistik biner. Hasilnya menunjukkan pasangan di daerah perkotaan lebih kecil kemungkinannya untuk memiliki ukuran keluarga $\leq 4$ dibandingkan pasangan yang tinggal di daerah pedesaan. Semakin baik status kekayaannya maka semakin tinggi kemungkinan memiliki ukuran keluarga $\leq 4$. Semakin lama kohabitasi maka semakin kecil kemungkinan memiliki ukuran keluarga $\leq 4$. Pasangan yang sudah memiliki jenis kelamin anak lengkap kemungkinannya 0,148 kali dibandingkan dengan yang tidak lengkap untuk memiliki ukuran keluarga $\leq 4$. Pemakaian alat kontrasepsi memiliki probabilitas 0,727 kali lipat dibandingkan dengan yang tidak menggunakannya untuk memiliki ukuran keluarga $\leq 4$. Suami yang berpendidikan dasar 1,242 kali lebih mungkin untuk memiliki ukuran keluarga $\leq 4$ dibanding keluarga dengan suami tidak berpendidikan. Usia istri menjadi faktor penentu ukuran keluarga. Pasangan dengan istri yang bekerja 1,273 kali lebih mungkin dibandingkan mereka yang tidak bekerja untuk memiliki ukuran keluarga $\leq 4$. Hasil penelitian menyimpulkan bahwa delapan variabel merupakan faktor-faktor yang memengaruhi ukuran keluarga pada pasangan usia subur di Indonesia. Delapan faktor tersebut adalah jenis tempat tinggal, status kekayaan, lama kohabitasi, jenis kelamin anak lengkap, penggunaan kontrasepsi, pendidikan suami, usia istri, dan status pekerjaan istri.

Kata Kunci: data kependudukan; keluarga berencana; melahirkan anak; ukuran keluarga

\section{Background}

Population growth in Indonesia continues to occur in relatively large numbers due to efforts to reduce the Population Growth Rate (PGR) and Total Fertility Rate (TFR) have not achieved the expected results yet. The government targets Indonesia's PGR to be projected from 1.49\%/ year in the 2000-2010 period to decline to $1.38 \% / y e a r$ in 2010-2015. Moreover, the target will drop again to $1.19 \% /$ year in 2015-2020 (Badan Kependudukan dan Keluarga Berencana Nasional [BKKBN], 2018).

Based on the 2017 Indonesian Demographic and Health Survey (IDHS) results, the TFR in Indonesia is 2.4. The achievement of this TFR is lower than the results of the same survey conducted in 2012, which is 2.6. However, this performance is still below the 2015-2019 Strategic Plan target, which is 2.3. The lowest TFR reduction nationally was achieved by the Province of East Java by 2.1. It defeated the Jakarta Province, which was also below the Strategic Plan's target, 2.2. Other provinces in Java, such as West Java, still rank 2.3 (BKKBN, 2018).

In general, the PGR and TFR are closely related to family size. All three are direct- ly proportional. The smaller the PGR and TFR, the smaller the average family size. Family size is the number of nuclear family members - a family of two parents and their children (one or more). The nuclear family is centered on married couples (The Editors of Encyclopaedia Britannica, 2018; Laksono, Soedirham, Saptandari, \& Wulandari, 2020).

There are several advantages to changing the family size to a smaller one. This condition applies not only to the household itself but also to the state or local government. Previous studies have suggested that a smaller family size can have an impact on better children's schools. This situation is especially true in developing countries. This condition is related to the family's limited funding so that the smaller number of children increases educational opportunities for them (Li \& Zhang, 2017; Weng, Gao, He, \& Li, 2019; Pan \& Liu, 2021).

On the other hand, family size is also related to socioeconomic implications. In Ghana, a previous study reported that small size families enjoyed better social and economical living. This condition is compared to families with relatively large family sizes (Arthur, 2005). Meanwhile, a 
study in Germany reported that the family size's demographic effect was greater for income before tax and benefits. On the other hand, the demographic trend with family size changes becomes smaller in population, reducing household inequality, poverty, and richness compared to before (Peichl, Pestel, \& Schneider, 2010). In general, a small family size provides a greater opportunity for each family member to enjoy a better life, both socially and economically. This situation has to do with distribution within the family (Chen, 2021; Chen, Zhao, Chou, \& Liem, 2021; Coley et al., 2021).

Some tribes in Indonesia are accustomed to large family sizes. The Lani tribe in Papua Province and the Aceh tribe in Aceh Province want to have 4 to 7 children. Both tribes assume that many children are needed to maintain the existence of their tribes. They reasoned that there were still a lot of lands that had not been cultivated in their area. The two tribes consider children to be assets, depending on old age (Wahyudi, Intiasari, \& Laksono, 2016; Laksono \& Wulandari, 2019).

The Javanese, the largest ethnic group in the country, also share similar principles. The tribe that inhabits most of the island of Java has the guidelines "many children, many fortunes," "each child brings his/her fortune." The Javanese believe that the more children they have, the more fortune the family will receive (Afidah, 2020; Pratita \& Laksono, 2020). The variety of local wisdom in the cultural context in Indonesia forms a significant family size norm in the family (Laksono, 2020).

Based on this background, this article was compiled to analyze the factors that correlate to family size among childbearing couples in Indonesia. This research is essential to identify the suitable policy targets for more specific family planning efforts in Indonesia.

\section{Methods}

\section{Data Source}

The author analyzed data from the 2017 Indonesian Demographic Data Survey (IDHS) as material in this study. The IDHS is part of an international survey of the Demographic and Health Survey program run by the Inner City Fund. The 2017 IDHS uses stratification and multistage random sampling to select the required samples. The unit of analysis in this study was the childbearing age couple in Indonesia. The sample size used was 34,353 couples.

\section{Availability of data and materials}

The authors cannot share data because a third party and authors who own the data do not have permission to share it. The 2017 IDHS data set name requested from the ICF (data set of childbearing age women) is available from the ICF contact (https://dhsprogram.com) for researchers who meet the access criteria confidential data.

\section{Study Variables}

Family size is the number of family members of fertile age couples and biological children. Moreover, the family size consists of two categories, namely $>4$ $($ code $=0)$ and $\leq 4(\operatorname{code}=1)$. The childbearing age pair were couples between men and women of childbearing age (15-49 years old).

Independent variables included in the analysis of this study are: (1) household characteristics, consisting of the type of place of residence, wealth status, marital status, cohabitation duration, complete child gender, and contraceptive use; (2) husband/men characteristics, consisting of age, education level, and occupation type; (3) wife/women characteristics, including age, education level, and employment status. 
The residence type consists of two: urban $(\operatorname{code}=1)$ and rural $(\operatorname{code}=2)$. The study determined wealth status based on the wealth index calculation. Meanwhile, the wealth index was a cumulative indicator of a household's overall standard of living. The IDHS measured the wealth index using readily available information on household ownership of specific properties such as televisions and bicycles, the materials used in housing construction, and the types of water and sanitation facilities available. The study broke down the wealth index into five categories: the poorest $(\operatorname{code}=1)$, poorer $(\operatorname{code}=2)$, middle (code $=3$ ), richer (code $=4)$, and the richest (code $=5$ ) (Wulandari, Supriyanto, Qomaruddin, \& Laksono, 2019; Wulandari \& Laksono, 2020b). Marital status consists of two categories: married $(\operatorname{code}=1)$ and living with partners (code=2).

Cohabitation duration was the length of a couple living together. The cohabitation duration consists of 7 levels: $<5$ years (code $=1), 5-9$ years $($ code $=2), 10-14$ years (code=3), 15-19 years (code $=4), 20-24$ years $($ code $=5), 25-29$ years $(\operatorname{code}=6)$, and $>29$ years $($ code $=7)$. Complete child gender completes the child's gender (son/s and daughter/s), which consists of not complete $($ code $=0)$ and complete $($ code $=1)$. Contraceptive use consists of two types: not using $(\operatorname{code}=0)$ and using $(\operatorname{code}=1)$.

The study calculated age based on the last birthday. Education level consists of 4 categories, namely no education (code $=0$ ), primary $(\operatorname{code}=1)$, secondary $(\operatorname{code}=2)$, and higher (code=3). Occupation type of husband/men was the type of work, consisting of did not work (code $=0$ ), professional/technical/managerial $(\operatorname{code}=1)$, clerical $($ code $=2)$, sales (code $=3)$, agricultural - self-employed (code=4), industrial workers (code $=5)$, services (code $=6$ ), and others (code=7). The employment status of wife/ women consists of two categories, namely not employed (code $=0$ ) and employed (code=1).

\section{Data Analysis}

The author tested all variables with a collinearity test to ensure no strong relationship between independent variables in the analysis's initial stage. The research performed a bivariate test using the chisquare test for dichotomous variables (all variables, except ages). At the same time, continuous variables use the T-test (age of wife and husband). In the final stage, the author used multinomial logistic regression because of the dependent variable's nature. The study carried out all statistical analyses using SPSS 22 software.

The author carried out interpretation of the binary logistic regression results with the following guidelines: OR $>1$ indicates the increased occurrence of an event or called risk exposure, $\mathrm{OR}<1$ indicates decreased occurrence of an event or called protective exposure.

\section{Ethical Approval}

The national ethics committee has approved ethical clearance for The 2017 IDHS. The study deleted all respondents' identities from the dataset. Respondents have provided written approval for their involvement in the research. The authors

Table 1.

\section{Results for the co-linearity test of family size among childbearing age couple in Indonesia $(n=34,353)$}

\begin{tabular}{llc}
\hline \multirow{2}{*}{\multicolumn{1}{c}{ Variables }} & \multicolumn{2}{c}{$\begin{array}{c}\text { Collinearity } \\
\text { Statistics }\end{array}$} \\
\cline { 2 - 3 } & $\begin{array}{c}\text { Tole- } \\
\text { rance }\end{array}$ & VIF \\
\hline Type of place of residence & 0.768 & 1.302 \\
Wealth status & 0.605 & 1.654 \\
Marital status & 0.976 & 1.024 \\
Cohabitation duration & 0.213 & 4.702 \\
Complete child gender & 0.791 & 1.264 \\
Contraceptive use & 0.957 & 1.045 \\
Husband/men age & 0.267 & 3.745 \\
Husband/men education level & 0.599 & 1.668 \\
Husband/men occupation type & 0.996 & 1.004 \\
Wife/women age & 0.189 & 5.289 \\
Wife/women education level & 0.540 & 1.851 \\
Wife/women employment status & 0.948 & 1.055 \\
\hline *Dependent Variable: Family size & \multicolumn{3}{c}{}
\end{tabular}


have obtained permission to use IDHS data of the 2017 data as material for analysis in this study from ICF International. They were applying for authorization through the website: https://dhsprogram.com.

\section{Results}

Table 1 displays the collinearity test results of all variables involved in family size analysis among childbearing age couples in Indonesia. The collinearity test shows that there is no co-linearity between the dependent and independent variables.

Table 1 shows that the tolerance value of all variables is more significant than 0.10. In comparison, the variance inflation factor (VIF) value for all variables is less than 10.00. Then referring to the basis

Table 2.

Descriptive statistics of family size by household characteristics in Indonesia $(n=34,353)$

\begin{tabular}{|c|c|c|c|c|}
\hline \multirow{3}{*}{$\begin{array}{c}\text { Household } \\
\text { Characteristics }\end{array}$} & \multicolumn{4}{|c|}{ Family Size } \\
\hline & \multicolumn{2}{|c|}{$>4$} & \multicolumn{2}{|c|}{$\leq 4$} \\
\hline & $\mathbf{n}$ & $\%$ & $\mathbf{n}$ & $\%$ \\
\hline \multicolumn{3}{|c|}{ Type of Place of Residence } & \multicolumn{2}{|r|}{${ }^{* * *} 0.000$} \\
\hline - Urban & 5615 & $47.3 \%$ & 11661 & $51.9 \%$ \\
\hline - Rural & 6260 & $52.7 \%$ & 10816 & $48.1 \%$ \\
\hline \multicolumn{3}{|l|}{ Wealth status } & \multicolumn{2}{|r|}{${ }^{\star * *} 0.000$} \\
\hline - Poorest & 3423 & $28.8 \%$ & 4530 & $20.2 \%$ \\
\hline - Poorer & 2258 & $19.0 \%$ & 4437 & $19.7 \%$ \\
\hline - Middle & 2102 & $17.7 \%$ & 4525 & $20.1 \%$ \\
\hline - Richer & 2042 & $17.2 \%$ & 4566 & $20.3 \%$ \\
\hline - Richest & 2050 & $17.3 \%$ & 4419 & $19.7 \%$ \\
\hline \multicolumn{3}{|l|}{ Marital status } & \multicolumn{2}{|r|}{${ }^{\star * *} 0.000$} \\
\hline \multirow{2}{*}{$\begin{array}{l}\text { - } \text { Married } \\
\text { - Living with } \\
\text { partner }\end{array}$} & 11809 & $99.4 \%$ & 22168 & $98.6 \%$ \\
\hline & 66 & $0.6 \%$ & 309 & $1.4 \%$ \\
\hline \multicolumn{3}{|c|}{ Cohabitation duration } & \multicolumn{2}{|r|}{${ }^{\star \star *} 0.000$} \\
\hline$-<5$ years & 21 & $0.2 \%$ & 5541 & $24.7 \%$ \\
\hline - 5-9 years & 701 & $5.9 \%$ & 5790 & $25.8 \%$ \\
\hline - 10-14 years & 1862 & $15.7 \%$ & 4119 & $18.3 \%$ \\
\hline - 15-19 years & 2947 & $24.8 \%$ & 3223 & $14.3 \%$ \\
\hline - 20-24 years & 2957 & $24.9 \%$ & 2148 & $9.6 \%$ \\
\hline - 25-29 years & 2261 & $19.0 \%$ & 1151 & $5.1 \%$ \\
\hline - > 29 years & 1126 & $9.5 \%$ & 505 & $2.2 \%$ \\
\hline \multicolumn{3}{|c|}{ Complete child gender } & \multicolumn{2}{|r|}{${ }^{* * *} 0.000$} \\
\hline - No & 2175 & $18.3 \%$ & 16529 & $73.5 \%$ \\
\hline - Yes & 9700 & $81.7 \%$ & 5948 & $26.5 \%$ \\
\hline \multicolumn{3}{|l|}{ Contraceptive Use } & \multicolumn{2}{|r|}{${ }^{\star * *} 0.000$} \\
\hline - No & 3774 & $31.8 \%$ & 9731 & $43.3 \%$ \\
\hline - Yes & 8101 & $68.2 \%$ & 12746 & $56.7 \%$ \\
\hline
\end{tabular}

Agung Dui Laksana \& Ratna Dui Wulandari of decision making in the multicollinearity test, it can be concluded that there were no multicollinearity symptoms in the regression model.

\section{Descriptive Results}

Table 2 is a descriptive statistic of family size by household characteristics in Indonesia. Groups > 4 dominate rural areas in the family size category, while group $\leq$ 4 is dominated in urban areas. Based on wealth status, group $>4$ is dominated by the poorest, while group $\leq 4$ is dominated by more affluent wealth status categories. Based on marital status, both family size groups are dominated by married couples.

Table 2 shows that couples with a family size $>4$ look dominant in the 20-24 years category based on cohabitation duration, while in the $\leq 4$ categories, the group is dominated by 5-9 years. Based on complete child gender, groups $>4$ are dominated by completed child gender, while group $\leq 4$ is dominated by uncompleted child gender. Meanwhile, based on

Table 3.

Descriptive statistics of family size by husband/men characteristics in Indonesia $(n=34,353)$

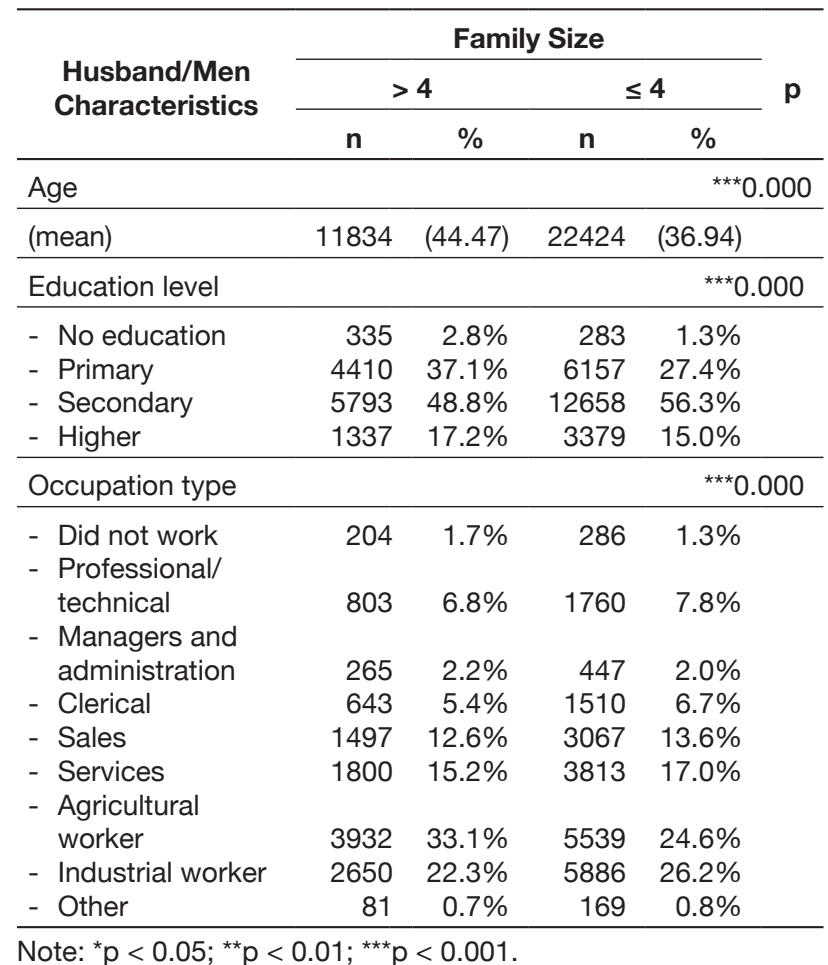

Faktar-Faktar yang Berhulungan dengan... 
contraceptive use, both groups are dominated by couples who use a contraceptive.

Table 3 is a descriptive statistic of family size by husband/men characteristics in Indonesia. Based on the husband/ men's age, the family size group $\leq 4$ has an average generation younger than the family size group $>4$. Meanwhile, based on husbands/men's education, both family size groups are dominated by husbands/ men with secondary education. Moreover, based on occupation type, the family size group $>4$ is dominated by agricultural worker husbands/men, while in the group, family size $\leq 4$ is dominated by industrial worker husbands/men.

Table 4 is a descriptive statistic of family size by wife/women characteristics in Indonesia. Based on the age of wife/ women, family size group $\leq 4$ has an average age younger than family size group $>$ 4. Based on wife/women's education level, both family size groups are dominated by wives/women with secondary education. Meanwhile, based on employment status, both family size groups are dominated by employed wives/women.

\section{Multivariable Analysis}

Table 5 results from a multinomial logistic regression test on family size among childbearing age couples in Indonesia. At this stage, this final analysis is to determine the determinant of family size among childbearing couples in Indonesia. As a reference, the chosen category was "family size $>4$ ". All variables were included in the analysis in the final step because the previous step proved all variables have a significant relationship with the dependent variable.

Table 5 shows that couples living in urban areas are 0.914 times more likely than couples living in rural areas to have a family size $\leq 4$ (OR 0.914; 95\% Cl 0.854-0.979). This information shows that couples in urban areas of Indonesia are less likely to have a family size $\leq 4$.
Table 4.

Descriptive statistics of family size by wife/women characteristics in Indonesia $(n=34,353)$

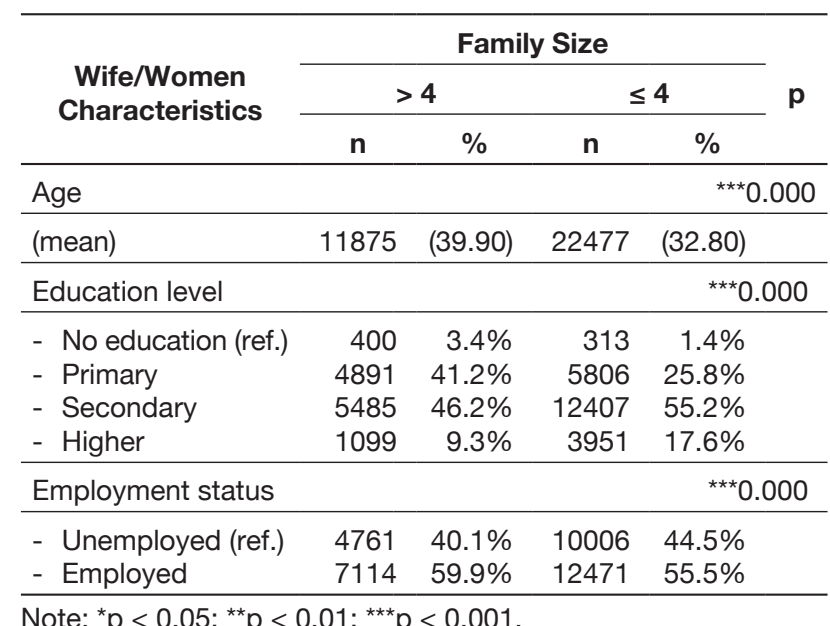

Table 5 informs that the poorer couple is 1.839 times more likely than the poorest to have a family size $\leq 4$ (OR 1.839; $95 \% \mathrm{Cl} 1.679-2.016)$. Couples with middle wealth status are 2.076 times more likely than the poorest to have a family size $\leq 4$ (OR 2.076; 95\% Cl 1.885-2.287). The richer couple has a 2.425 times higher probability than the poorest to have a family size $\leq 4$ (OR 2.425; 95\% Cl 2.189-2.687). The richest couple has a possibility of 2.709 times higher than the poorest to have a family size $\leq 4$ (OR 2.709; 95\% Cl 2.414-3.040). This information shows that the better the wealth status of a couple, the higher the possibility of having a family size $\leq 4$.

Table 5 shows that couples who have been together for 5-9 years are 0.060 times more likely than couples who are $<5$ years old to have a family size $\leq 4$ (OR 0.060; $95 \% \mathrm{Cl}$ 0.039-0.094). Couples who have been together for 15-19 years are 0.010 times more likely than couples who are < 5 years to have a family size $\leq 4$ (OR 0.010 ; 95\% Cl 0.006-0.016). Couples who have been together for 25-29 years are 0.005 times more likely than couples $<5$ years to have a family size $\leq 4$ (OR 0.005; $95 \% \mathrm{Cl}$ 0.003-0.008). This information shows that the longer the cohabitation period, the less likely a family size $\leq 4$. 
Table 5.

Multinomial logistic regression of family size among childbearing age couple in Indonesia $(n=34,353)$

\begin{tabular}{|c|c|c|c|c|}
\hline \multirow{3}{*}{ Predictors } & \multicolumn{4}{|c|}{ Family Size ( $\leq 4)$} \\
\hline & \multirow[t]{2}{*}{$\mathrm{p}$-value } & \multirow[t]{2}{*}{ OR } & \multicolumn{2}{|l|}{$95 \% \mathrm{Cl}$} \\
\hline & & & $\begin{array}{l}\text { Lower } \\
\text { Bound }\end{array}$ & $\begin{array}{l}\text { Upper } \\
\text { Bound }\end{array}$ \\
\hline \multicolumn{5}{|l|}{ Household Characteristics } \\
\hline Type of Place of Residence: Urban & *0.010 & 0.914 & 0.854 & 0.979 \\
\hline Type of Place of Residence: Rural & - & - & - & \\
\hline Wealth status: Poorest & - & - & - & \\
\hline Wealth status: Poorer & ${ }^{* * *} 0.000$ & 1.839 & 1.679 & 2.016 \\
\hline Wealth status: Middle & ${ }^{* * \star} 0.000$ & 2.076 & 1.885 & 2.287 \\
\hline Wealth status: Richer & ${ }^{\star * \star} 0.000$ & 2.425 & 2.189 & 2.687 \\
\hline Wealth status: Richest & ${ }^{\star \star *} 0.000$ & 2.709 & 2.414 & 3.040 \\
\hline Marital: Married & 0.064 & 1.425 & 0.980 & 2.071 \\
\hline Marital: Living with partner & - & - & - & \\
\hline Cohabitation duration: $<5$ years & - & - & - & \\
\hline Cohabitation duration: $5-9$ years & ${ }^{* \star *} 0.000$ & 0.060 & 0.039 & 0.094 \\
\hline Cohabitation duration: $10-14$ years & ${ }^{\star \star \star} 0.000$ & 0.020 & 0.013 & 0.031 \\
\hline Cohabitation duration: $15-19$ years & ${ }^{* * *} 0.000$ & 0.010 & 0.006 & 0.016 \\
\hline Cohabitation duration: $20-24$ years & ${ }^{\star \star \star} 0.000$ & 0.007 & 0.004 & 0.011 \\
\hline Cohabitation duration: $25-29$ years & ${ }^{\star \star \star} 0.000$ & 0.005 & 0.003 & 0.008 \\
\hline Cohabitation duration: $>29$ years & ${ }^{* \star \star} 0.000$ & 0.004 & 0.002 & 0.006 \\
\hline Complete child gender: No & - & - & - & \\
\hline Complete child gender: Yes & ${ }^{* * \star} 0.000$ & 0.148 & 0.139 & 0.157 \\
\hline Contraceptive Use: No & - & - & - & \\
\hline Contraceptive Use: Yes & ${ }^{\star \star \star} 0.000$ & 0.727 & 0.683 & 0.774 \\
\hline \multicolumn{5}{|l|}{ Husband/Men Characteristics } \\
\hline Age & 0.633 & 1.001 & .995 & 1.008 \\
\hline Education level: No education & - & - & - & \\
\hline Education level: Primary & ${ }^{*} 0.047$ & 1.242 & 1.003 & 1.537 \\
\hline Education level: Secondary & 0.673 & 1.048 & .843 & 1.303 \\
\hline Education level: Higher & 0.152 & 0.837 & 0.655 & 1.068 \\
\hline Occupation type: Did not work & - & - & - & \\
\hline Occupation type: Professional/technical/managerial & 0.388 & 0.890 & 0.682 & 1.160 \\
\hline Occupation type: Clerical & 0.616 & 0.924 & 0.678 & 1.259 \\
\hline Occupation type: Sales & 0.301 & 0.867 & 0.662 & 1.136 \\
\hline Occupation type: Agricultural - self-employed & 0.597 & 0.934 & 0.726 & 1.202 \\
\hline Occupation type: Industrial worker & 0.950 & 1.008 & 0.785 & 1.294 \\
\hline Occupation k type: Services & 0.883 & 1.019 & 0.796 & 1.303 \\
\hline Occupation type: Other & 0.197 & 1.176 & 0.919 & 1.505 \\
\hline Wife/Women Characteristics & 0.281 & 0.798 & 0.529 & 1.203 \\
\hline Age & *0.027 & 0.990 & 0.982 & .999 \\
\hline Education level: No education & - & - & - & \\
\hline Education level: Primary & 0.573 & 1.058 & 0.869 & 1.288 \\
\hline Education level: Secondary & 0.906 & 1.012 & 0.827 & 1.240 \\
\hline Education level: Higher & 0.657 & 0.949 & 0.754 & 1.194 \\
\hline Employment status: Unemployed & - & - & - & \\
\hline Employment status: Employed & ${ }^{\star \star \star} 0.000$ & 1.273 & 1.198 & 1.353 \\
\hline
\end{tabular}

Note: $95 \% \mathrm{Cl} ;{ }^{\star} \mathrm{p}<0.05 ;{ }^{* \star} \mathrm{p}<0.01 ;{ }^{* \star *} \mathrm{p}<0.001$. 
Table 5 informs that couples with complete child gender are 0.148 times more likely than couples who do not have complete child gender to have a family size $\leq 4$ (OR 0.148; 95\% Cl 0.139-0.157). The result means couples who have complete child gender have a lower probability of having a family size $\leq 4$. Meanwhile, Table 3 shows that couples who use contraceptives are 0.727 times more likely than couples who do not use contraceptives to have a family size $\leq 4$ (OR $0.727 ; 95 \% \mathrm{Cl}$ 0.683-0.774).

Table 5 shows that the age and occupation type of husband/man is not of the determinant family sizes. Meanwhile, the education level of husbands/men is partially a determinant of family size. The couples with a husband/men who have primary education are 1.242 times more likely than couples with no education husband/men to have a family size $\leq 4$ (OR 1.242; 95\% Cl 1.003-1.537).

Table 5 shows that the age of the wife/ woman is one of the determinant family sizes. Meanwhile, the education level of wife/woman is not one of Indonesia's determinant family sizes. Finally, Table 5 informs that couples with employed wives/ women are 1.273 times more likely than couples with unemployed wives/women to have a family size $\leq 4$ (OR 1.273; 95\% $\mathrm{Cl}$ 1.198-1.353). The information means a wife/woman who has a job is one of the protective factors for a childbearing age couple to have a family size $\leq 4$ in Indonesia.

\section{Discussion}

Generally, family size affects and is influenced by social factors at the individual and population levels, including the availability of health services and family planning (Wulandari \& Laksono, 2019). In industrialized countries, there is a tendency for high levels of education for women, delayed marriages/partnerships, and delayed childbearing associated with smaller family sizes. On the other hand, intense religiosity is associated with larger family size (Zito \& Constantine, 2016).

The study results inform that in urban areas in Indonesia, the probability of a couple having a family size $\leq 4$ is smaller than that of a couple who lives in rural areas. This condition contradicts family planning information, which tends to be more massive in urban areas than in rural areas (Sariyati \& Alfiana, 2013; Laksono, Wulandari, \& Soedirham, 2019; Seran et al., 2020). On the other hand, a study on urban slums in India informs findings that explain the causes of family planning programs' low-performance achievement in urban areas. The study found that the unmet need for family planning services is very high in urban slums (Yadav, Agarwal, Shukla, Singh, \& Singh, 2020).

The results found that the better the wealth status of childbearing age couples, the higher the possibility of having a family size $\leq 4$. A study in the United States that investigated the relationship between wealth status owned by families with depressive symptoms informs that families with large family sizes have the possibility of experiencing depression compared to families with smaller sizes. This condition is possible because low family savings must be allocated to many family members (Ettman, Cohen, \& Galea, 2020). Large family size is also closely related to large energy consumption, so it significantly affects expenses incurred by the family (Jakučionytè-Skodienè, Dagiliūtè, \& Liobikienè, 2020). Specifically, a study in Nigeria informs that local people who choose to work in agriculture decide to have a small family size. The situation relates to income and time availability for family and work (Umeh et al., 2020).

The study's findings inform that the longer the cohabitation period is owned by a childbearing age couple, the lower the likelihood of having a family size $\leq 4$. The duration of partnership in the household has been generally known as one factor affecting family size. The cohabitation peri- 
od is positively related to family size. The longer the partnership of husband and wife, the more likely it is to have any children (Zito \& Constantine, 2016).

Couples who have complete child gender have a lower possibility of having a family size $\leq 4$. In certain cultures, the number of children is related to children's value, specifically to gender preference, often son/s (Bagheri \& Saadati, 2018; Kusrini, Ipa \& Laksono, 2019; Ngo, 2020). The value of children in families that tend to be one of the genders tends to increase the number of children if the desired gender has not been obtained. The condition encourages the formation of larger family sizes (Laksono \& Wulandari, 2019; Sivak \& Smirnov, 2019; Wulandari \& Laksono, 2021).

Couples using contraception are less likely to have a family of $\leq 4$ than couples who do not use contraception. Most married couples use contraception after feeling the child they want is enough. The number of pairs of contraceptive users who think the number of children is sufficient is more significant. This amount is compared to couples who use contraception to widen their birth spacing after having children (Kibria et al., 2016; Ariho \& Kabagenyi, 2020).

Couples with husbands/men with primary education have a higher possibility than teams with no education husband/ men to have a family size $\leq 4$. This information explains that education influences the understanding of the couple in planning the future of the household. Furthermore, children born in smaller family sizes can better Education Education (Chen, 2017; Weng et al., 2019). This condition is related to the availability of family-owned resources distributed to a smaller number of family members (Shen, 2017; Liang \& Gibson, 2018).

In several previous studies, better education was always associated with better performance output in the health sector (Ipa, Widawati, Laksono, Kusri- ni, \& Dhewantara, 2020; Megatsari et al., 2020; Wulandari \& Laksono, 2020a). Meanwhile, lower education is often a barrier to achieving better community programs' performance (Laksono \& Wulandari, 2020; Rohmah et al., 2020). Specifically, the link between family size and intelligence was reported in research in Japan and Libya. The study informs us that there are possibilities that show unfavorable intellectual development conditions in families with larger family sizes. Another opportunity is differential reproduction in favor of less intelligent parents (Kanazawa, 2012; Al-Shahomee \& Lynn, 2018).

The results found that the age of wife/ woman is one of the determinant family sizes. The age composition between husband and wife influences the maturity of choice to form a family size. Specifically, the effect of age is more robust in the wife's age (Zito \& Constantine, 2016). Biologically, age is closely related to fertility in reproductive function, especially in women (Araban, Karimy, Armoon, \& Zamani-Alavijeh, 2020).

The study results inform that a wife/ woman's employment status is one of the protective factors for a childbearing age couple to have a family size $\leq 4$ in Indonesia. These findings indicate that working women tend to be more aware of the limited time available to care for children, so they choose a smaller family size. In the context of Indonesia, caring for children is an obligation for women as part of domestic duties (Pratiwi, Fitrianti, Nuraini, Rachmawati, \& Laksono, 2019; Kusrini \& Laksono, 2020; Laksono \& Megatsari, 2020).

\section{Conclusions}

Based on the analysis results, the study concluded that eight variables correlated to family size among childbearing age couples in Indonesia. The eight variables were the type of place of residence, wealth status, cohabitation duration, complete child gender, contraceptive use, husband's 
education, wife's age, and wife's employment status.

Based on the research results, the government or policymaker can focus on the policy targets according to the results of the analysis of this study if it wants to accelerate the coverage of small families with two children in Indonesia. Policymakers can target couples who live in urban areas, are poor, are not legally married (living with partners), cohabitation duration in $<5$ years, do not have children with complete gender, husbands or wives with low education, and unemployed wives.

\section{Acknowledgments}

The author would like to thank the Inner City Fund International, which has agreed to allow the 2017 IDHS data to be analyzed in this article.

\section{Declaration of Conflicting Interests}

The authors declared no potential conflicts of interest concerning the research, authorship, and publication of this article.

\section{References}

Afidah, N. N. (2020). Kampung keluarga berencana sebagai upaya mengubah paradigma mitos banyak anak banyak rezeki. Prosiding Seminar Nasional Bahasa dan Sastra Indonesia Sasindo Unpam 2019, Pamulang, Universitas Pamulang, 1(2), 94-108. Diakses dari http://www. openjournal.unpam.ac.id/index.php/ Proceedings/article/view/4062

Al-Shahomee, A. A., \& Lynn, R. (2018). Intelligence and family size in Libya. The Mankind Quarterly, 59(2), 255-265.

Araban, M., Karimy, M., Armoon, B., \& ZamaniAlavijeh, F. (2020). Factors related to childbearing intentions among women: A cross-sectional study in health centers, Saveh, Iran. Journal of the Egyptian Public Health Association, 95(1), 1-8. doi: 10.1186/s42506-020-0035-4
Ariho, P., \& Kabagenyi, A. (2020). Age at first marriage, age at first sex, family size preferences, contraception and change infertility among women in Uganda: Analysis of the 2006-2016 period. BMC Women's Health, 20(1), Article number 8. doi: 10.1186/s12905-020-0881-4

Arthur, J. L. (2005). Family size and its socioeconomic implications in the Sunyani Municipality of the Brong Ahafo Region of Ghana, West Africa. Ghana: Centre for Development Studies, Faculty of Social Science, University of Cape Coast. Unpublish. Diakses dari http://www.ciesin. org/documents/arthurjl.pdf

Bagheri, A., \& Saadati, M. (2018). Value of children: attitudinal factors influencing childbearing desire of Iranian women. Women's Health Bulletin, 5(4), 1-6. doi: 10.5812/whb.79370

Badan Kependudukan dan Keluarga Berencana Nasional [BKKBN]. (2018, Januari 30). Deputi KBKR: angka fertilitas wanita Indonesia alami penurunan. Diakses dari https://www.bkkbn.go.id/ detailpost/deputi-kbkr-angka-fertilitaswanita-indonesia-alami-penurunan

Chen, C., Zhao, W., Chou, S. Y., \& Lien, H. M. (2021). The effect of family size on parents' labor supply and occupational prestige: Evidence from Taiwan and Mainland China. China Economic Review, 66, 101596.

Chen, Q. (2017). Relaxed population policy, family size, and parental investments in children's education in rural Northwestern China. International Journal of Educational Development, 54, 39-50. doi: 10.1016/j. ijedudev.2017.03.009

Chen, Q. (2021). Population policy, family size and child malnutrition in Vietnam - Testing the trade-off between child quantity and quality from a child nutrition perspective. Economics and Human Biology, 41, Article number 100983. doi: 10.1016/j. ehb.2021.100983

Coley, R. L., Spielvogel, B., Kruzik, C., Miller, P., Betancur, L., \& Votruba-Drzal, E. (2021). Explaining income disparities in young children's development: The role of community contexts and family processes. Early Childhood Research 
Quarterly, 55, 295-311. doi: 10.1016/j. ecresq.2020.12.006

Ettman, C. K., Cohen, G. H., \& Galea, S. (2020). Is wealth associated with depressive symptoms in the United States? Annals of Epidemiology, 43, 25-31. doi: 10.1016/j. annepidem.2020.02.001

Ipa, M., Widawati, M., Laksono, A. D., Kusrini, I., \& Dhewantara, P. W. (2020). Variation of preventive practices and its association with malaria infection in eastern Indonesia: Findings from community-based survey. PLOS ONE, 15(5) e0232909. doi: 10.1371/ journal.pone.0232909

Jakučionytè-Skodienè, M., Dagiliūtè, R., \& Liobikienè, G. (2020). Do general proenvironmental behaviour, attitude, and knowledge contribute to energy savings and climate change mitigation in the residential sector? Energy, 193, Article number 116784. doi: 10.1016/j. energy.2019.116784

Kanazawa, S. (2012). Intelligence, Birth Order, and Family Size. Personality and Social Psychology Bulletin, 38, 1157-1164. doi: $10.1177 / 0146167212445911$

Kibria, G. M. A., Hossen, S., Barsha, R., Sharmeen, A, Paul, S. K., \& Uddin, S. M. I. (2016). Factors affecting contraceptive use among married women of reproductive age in Bangladesh. Journal of Molecular Studies and Medicine Research, 2(1), 7079. doi: 10.18801/jmsmr.020116.09

Kusrini, I., Ipa, M., \& Laksono, A. D. (2019). Is It true that the child is king?: Qualitative study of factors related to nutritional status of children in West Lombok, Indonesia. Indian Journal of Public Health Research and Development, 10(12), 1729-1733. doi: 10.37506/v10/i12/2019/ijphrd/192113

Kusrini, I., \& Laksono, A. D. (2020). Regional disparities of stunted toddler in Indonesia. Indian Journal of Forensic Medicine and Toxicology, 14(3), 1685-1691.

Laksono, A. D. (2020). Tengger bertahan dalam adat: studi konstruksi sosial ukuran keluarga suku Tengger. Surabaya: Health Advocacy.

Laksono, A. D., Soedirham, O, Saptandari, P., \& Wulandari, R. D. (2020). Study of family size among Tenggerese in Indonesia. International Journal of Innovation, Creativity and Change, 13(4), 964-978.

Laksono, A. D., \& Megatsari, H. (2020). Determinan balita stunting di Jawa Timur: Analisis data pemantauan status gizi 2017. Amerta Nutrition, 4(2), 109-115. doi: 10.2473/amnt.v4i2.2020.109-115

Laksono, A. D., \& Wulandari, R. D. (2019). "Anak adalah aset": Meta sintesis nilai anak pada Suku Lani dan Suku Aceh. Jurnal Kesehatan Reproduksi, 10(1), 1120. doi: 10.22435/kespro.v10i1.933.11-20

Laksono, A. D., \& Wulandari, R. D. (2020). The Barrier to maternity care in rural Indonesia. Journal of Public Health. 1-6. doi: 10.1007/ s10389-020-01274-3

Laksono, A. D., Wulandari, R. D., \& Soedirham, O. (2019). Urban and rural disparities in hospital utilization among Indonesian adults. Iranian Journal of Public Health, 48(2), 247-255. doi: 10.18502/ijph. v48i2.819

Li, B., \& Zhang, H. (2017). Does population control lead to better child quality? Evidence from China's one-child policy enforcement. Journal of Comparative Economics, 45(2), 246-260. doi: 10.1016/j. jce.2016.09.004

Liang, Y., \& Gibson, J. (2018). Do siblings take your food away? Using China's one-child policy to test for child quantity-quality trade-offs. China Economic Review, 48, 14-26. doi: 10.1016/j.chieco.2017.10.006

Megatsari, H., Laksono, A. D., Ibad, M., Herwanto, Y. T., Sarweni, K. P., Geno, R. A. P., \& Nugraheni, E. (2020). The community psychosocial burden during the COVID-19 pandemic in Indonesia. Heliyon, 6(10), Article number e05136. doi: 10.1016/j.heliyon.2020.e05136

Ngo, A. P. (2020). Effects of Vietnam's twochild policy on fertility, son preference, and female labor supply. Journal of Population Economics, 33, 751-794. doi: 10.1007/ s00148-019-00766-1

Pan, Y., \& Liu, Y. (2021). Birth control, family size, and educational stratification: Evidence from the Han and ethnic minorities in China. Economics 
of Education Review, 81, Article number 102078. doi: 10.1016/j. econedurev.2021.102078

Peichl, A., Pestel, N., \& Schneider, H. (2012). Does size matter? The impact of changes in household structure on income distribution in Germany (Discussion Paper No. 4770). Bonn, Germany: IZA. Diakses dari http://ftp.iza.org/dp4770.pdf

Pratita, I., \& Laksono, A. D. (2020). "Anak ini kalau makan, ya apapun yang diminta...": Eksplorasi nilai anak dan pola pengasuhan anak pada Suku Jawa di Desa Besowo, Kediri, Jawa Timur. Amerta Nutrition, 4(2), 147-154. doi: 10.20473/amnt. v4i2.2020.147-154

Pratiwi, N. L., Fitrianti, Y., Nuraini, S., Rachmawati, T., \& Laksono, A. D. (2019). Ibu Hamil "Kemel" Pada Etnis Gayo Di Kecamatan Blang Pegayon Kabupaten Gayo Lues, Aceh. Bulletin of Health System Research, 22(2), 81-90. doi: 10.22435/hsr. v22i2.1693

Rohmah, N., Yusuf, A., Hargono, R., Laksono, A. D., Ibrahim, I., \& Walid, S. (2020). Determinants of teenage pregnancy in Indonesia. Indian Journal of Forensic Medicine \& Toxicology, 14(3), 2105-2110.

Sariyati, S., \& Alfiana, H. (2013). Gambaran keinginan unmet need terhadap pelayanan KB di Kota Yogyakarta. Jurnal Ners dan Kebidanan Indonesia, 1(3), 105-107. doi: 10.21927/jnki.2013.1(3).105-107

Seran, A. A., Artaria, M. D., Haksama, S., Setijaningrum, E., Laksono, A. D., \& Sujoso, A. D. P. (2020). Disparities of the use of hormonal and non-hormonal contraceptive drugs in urban and rural areas in Indonesia and the world. Systematic Reviews in Pharmacy, 11(9), 66-73. doi: 10.31838/srp.2020.9.12

Shen, Y. (2017). The effect of family size on children's education: Evidence from the fertility control policy in China. Frontiers of Economics in China, 12(1), 37-65. doi: 10.3868/s060-006-017-0003-3

Sivak, E., \& Smirnov, I. (2019). Parents mention sons more often than daughters on social media, in Nelson, L. K. (ed.). Proc Natl Acad Sci U S A. PNAS, 116(6), 2039-2041. doi: 10.1073/pnas.1804996116
The Editors of Encyclopaedia Britannica. (2018). Nuclear family. Diakses dari https:// www.britannica.com/topic/nuclear-family

Umeh, N. G., Nwibo, S. U., Nwofoke, C., Igboji, C., Ezeh, A. N., \& Mbam, N. B. (2020). Socio-economic determinants of agripreneurship choice among youths in Ebonyi State, Nigeria. Journal of Agricultural Extension, 24(1), 24-33. doi: 10.4314/jae.v24i1.3

Wahyudi, A., Intiasari, A. D., \& Laksono, A. D. (2016). Potret pola asuh 'anak noken' dalam budaya Lani. Surabaya: Unesa University Press.

Weng, Q., Gao, X., He, H., \& Li, S. (2019). Family size, birth order and educational attainment: Evidence from China. China Economic Review, 57, Article number 101346. doi: 10.1016/j. chieco.2019.101346

Wulandari, R. D., Supriyanto, S., Qomaruddin, B., \& Laksono, A. D. (2019) Socioeconomic disparities in hospital utilization among elderly people in Indonesia. Indian Journal of Public Health Research and Development. Surabaya, 10(11), 1800-1804. doi: 10.5958/09765506.2019.03885.3

Wulandari, R. D., \& Laksono, A. D. (2019). Hubungan antara rasio bidan dengan kinerja program kesehatan ibu dan anak di Indonesia. Buletin Penelitian Sistem Kesehatan, 22(3), 208-214. doi: 10.22435/ hsr.v22i3.1740

Wulandari, R. D., \& Laksono, A. D. (2020a). Education as a predictor of the knowledge of pregnancy danger signs in Rural Indonesia. International Journal of Innovation, Creativity, and Change, 13(1), 1037-1051.

Wulandari, R. D., and Laksono, A. D. (2020b). Hubungan status ekonomi terhadap pernikahan dini pada perempuan di perdesaan Indonesia. Jurnal Kesehatan Reproduksi, 11(2), 115-124. doi: 10.22435/ kespro.v11i2.3870.115-124

Wulandari, R. D., \& Laksono, A. D. (2021). Hubungan paritas dan karakteristik individu terhadap pemakaian alat kontrasepsi di antara wanita usia subur di Provinsi Jawa Timur tahun 2017. Buletin 
Penelitian Sistem Kesehatan, 24(1), 20-30. doi: 10.22435/hsr.v24i1.3038

Yadav, K., Agarwal, M., Shukla, M., Singh, J. V., \& Singh, V. K. (2020). Unmet need for family planning services among young married women (15-24 years) living in urban slums of India. BMC Women's Health, 20(1), Article number 187. doi: 10.1186/s12905-020-01010-9

Zito, R. C., \& Constantine, P. (2016). Family size, in Shehan, C. L. (ed.) The Wiley Blackwell Encyclopedia of Family Studies (first volume). New Jersey, USA: JohnWiley \& Sons, Inc. doi: 10.1002/9781119085621. wbefs081 